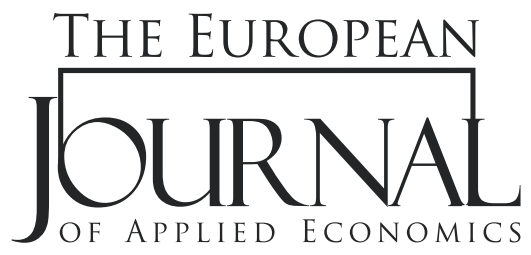

\title{
IS WORKING CAPITAL MANAGEMENT ABLE TO INCREASE SUSTAINABLE GROWTH THROUGH ASSET UTILIZATION?
}

\author{
Pambayun Kinasih Yekti Nastiti, Apriani Dorkas Rambu Atahau, Supramono Supramono* \\ Management Department, Faculty of Economics and Business, \\ University of Kristen Satya Wacana, \\ Indonesia
}

\begin{abstract}
:
Working capital management has a strategic role to maintain a balance between liquidity and profitability so that firms have greater opportunities to operate sustainably. This study mainly aims to investigate the ability of working capital management to increase sustainable growth through asset utilization. We ran panel data regression on manufacturing firms listed in the Indonesian Stock Exchange for the years of 2010-2017 as our sample. By controlling for leverage, sales growth, and firm size, our empirical results demonstrate that working capital management negatively affects firms' asset utilization. Furthermore, the study also finds that asset utilization positively affects sustainable growth. Finally, we empirically show that asset utilization mediates the relationship between working capital management and sustainable growth. The findings imply that if Indonesian manufacturing firms manage to have efficient working capital management, they are more likely to utilize their assets efficiently which, in turn, will increase their growth optimally, without causing problems to their cash.
\end{abstract}

\section{Article info:}

Received: April 9, 2020

Correction: May 19, 2020

Accepted: September 3, 2020

\section{Keywords:}

working capital management, asset utilization, sustainability growth, cash conversion cycle.

\section{INTRODUCTION}

Poor working capital management is the main cause of business failure (Smith, 1973). Consequently, numerous financial managers devote a great proportion of their time to manage working capital (Palombini \& Nakamura, 2012; Botoc \& Anton, 2018; Wang, Akbar, \& Akbar, 2020). However, studies in working capital management so far are less developed than similar studies in the domain of long-term investing, financing, and dividend decisions (Palombini \& Nakamura, 2012; Singh, Kumar, \& Colombage 2017).

Previous studies have analyzed the role of working capital management in terms of its effects on profitability (Deloof, 2003; Sharma, \& Kumar, 2010; Marttonen, Monto, \& Kärri,2013; Aregbeyen, 2017; 
Gorondutse, Abubakar, Ali, \& Naalah,,2017; Hien Tran, Abbott \& Jin-Yap, 2017;), liquidity (Adekola, Samy \& Knight, 2017), and firm value (Kieschnick, Laplante , \& Moussawi, 2013; Baños-Caballero, García-Teruel, \& Martínez-Solano, 2014; De Almeida., \& Eid,2014; Wasiuzzaman, 2015, ). Thus, firms need to have a good ability to manage their working capital (Deloof, 2003; Adekola et al., 2017).

Working capital management not only affects firms' performance but also their asset utilization or commonly known as total asset turnover. Asset turnover informs us whether firms have utilized their assets efficiently (Rahim, 2017; Alarussi \& Alhaderi, 2018; Zorn, Esteves ,Baur, \& Lips, 2018). A greater asset turnover indicates that firms manage to generate higher sales with the same level of assets or to generate the same sales with fewer assets. Firms will achieve both conditions if they manage their working capital efficiently.

Rahim (2017) and Manaf et al..(2018) demonstrate that asset utilization affects firms' ability to grow optimally based on their internal financing or commonly known as sustainable growth. Ashta (2008) underscores that sustainable growth indicates the extent of firms' ability to grow without negatively affecting their cash flows. Consequently, firms that focus on their growth should also take sustainable growth into consideration to avoid financial distress or even bankruptcy (Fonseka et al., 2012). The decision on financing sources to capture growth opportunities is a strategic one for firm managers (Ganiyu, 2018). Meanwhile, Churcill and Mullins (2001) propose that sustainable growth is closely related to working capital management. However, they do not explain further how these two variables are related. It is then predicted that working capital management affects sustainable growth through asset utilization.

This study aims to test (a) the effect of working capital management on asset utilization, (b) the effect of asset utilization on sustainable growth, and (c) the effect of working capital management on sustainable growth through asset utilization. By doing so, this study will contribute to the working capital management literature by offering a better understanding of the relationship between working capital management, asset utilization, and sustainable growth. It is worth noting that previous studies have not investigated the effect of working capital management on sustainable growth as mediated by asset utilization. Practically, it is expected that the results of this study will help managers make more specific plans to enhance their firms' sustainable growth through working capital management and asset utilization.

\section{LITERATURE REVIEW}

Working capital management is the decision that is related to the management of current assets and current liabilities and the interrelationship between these two accounts (Abuzayed, 2012). Some firms exhibit a great proportion of current assets to total assets and a substantial proportion of current liabilities in their financing activities (Shapiro \& Balbirer, 2000). Working capital management also refers to net current assets investing, financing, and controlling activities through firms' various policies (Padachi et al, 2012). Further, Dhole, Mishra, \& Pal(2019) emphasize the importance of working capital management to avoid excessive working capital while at the same time to prevent firms from lacking working capital. A commonly used indicator of working capital management is the cash conversion cycle (Deloof, 2003; Abuzayed, 2012; Hien Tran et al., 2017). A short cash conversion cycle implies efficient working capital management.

Working capital management will affect firms' asset utilization (Rahim, 2017). Assets utilization is the use of firms assets to produce products or services offered to consumers (Rahayu, 2019). It is measured by the ratio between sales and total assets. Thus, the effect of working capital management on asset utilization is through more efficient utilization of short-term assets and increased sales, despite the unique feature of the relationship due to the trade-off between these two factors. On the one hand, firms utilize their current assets efficiently by reducing their investments in receivables and inventories. Consequently, such reductions will shorten receivables and inventory turnover. 
On the other hand, firms are likely to increase sales by loosening their credit sales policies (Martínez-Sola, García-Teruel, \& Martínez-Solano, 2012; Tauringana \& Afrifa, 2013,) because customers have a longer time to pay their payables. Although many consider receivables to be unwanted assets so the firms try to shorten the collection period for accounts receivables (Hofmann, \& Kotzab, 2010; Botoc \& Anton, 2017), receivables are often unavoidable for firms because firms are likely to lose their customers if they cannot compete with their competitors in granting credits (Molina, \& Preve,2009). By granting credits, firms offer opportunities for their customers to evaluate the quality of their products before paying. Thus, these offers are arguably more attractive to customers (Deloof, 2003). Moreover, firms have policies to increase inventories to increase sales (Abuzayed, 2012), because firms that have a sufficient level of inventories are more likely to avoid production problems (Garcia-Teruel \& MartinezSolano, 2007) that will cause firms to lose opportunities to realize sales (Wang, et al., 2020). All in all, efforts to increase sales will need a longer cash conversion cycle.

Asset utilization is likely to affect firms' sustainable growth (Shapiro \& Balbirer, 2000). Firms should focus on their sustainable growth, not just a high level of sales growth, by adjusting their growth with their existing financing ability to ensure their sustainability. Higgins (1977) introduces the concept of sustainable growth that refers to the level of annual sales growth that is consistent with firms' financial policies. These financial policies are related to firms' decisions not to issue new shares and to maintain the debt to equity ratio at certain levels. Consequently, sales growth largely depends on internal financing sources. The policy is also in line with the view of the pecking order theory, which states that companies prefer to use internal financing sources rather than external sources (Račić \& Stanišić, 2017).

Higgins (1977) explains that sustainable growth is affected by dividend policy, leverage policy, and asset utilization policy. Firms with more efficient asset utilization will manage to reduce the needs of assets that will lead to reduced costs, and eventually increased sustainable growth. In a similar vein, Kester (2002) argue that a consequence of increasing sustainable growth is that firms have to utilize their assets more efficiently. In other words, firms do not have to add assets to increase their sales (Rahim, 2017). Fonseka et. al (2012) empirically shows that total asset turnover affects firms' sustainable growth. Thus, it can be predicted that asset utilization not only affects sustainable growth, but also mediates the effect of working capital management on sustainable growth.

\section{METHODOLOGY}

\section{Data Sample}

We generated our data from the annual reports of 165 manufacturing firms listed in the Indonesian Stock Exchange for the years of 2010-2017. We use manufacturing firms as our sample because these firms arguably exhibit higher investments in working capital than other firms. Firms with incomplete financial statements contain items needed to measure the research variables, negative book equity values, and outliers for certain variables in any of the years of sample period have not been included in this study, thus our final sample consists of 137 firms. Data sources are firms' formal websites, the website of the Indonesian Stock Exchange (http://www.idx.co.id), and IDN Financials (https://www. idnfinancials.com). 


\section{Measurement}

Our variables of interest include the dependent variable (sustainable growth), the independent variables (working capital management), and the mediating variable (asset utilization). We measure sustainable growth by using the sustainable growth rate (SGR), that is, the multiplication between ROE and Retention Rate (Higgins 1977). Meanwhile, working capital management as empirically measured by cash conversion cycle (CCC), which shows the period needed by firms to convert their cash outflows to cash inflows. Next, we used total asset turnover as a measure of asset utilization. Further, we referred to previous studies (Padachi et al., 2012; Hien Tran et al., 2017; Laghari \& Chengang, 2019) in using firm size, sales growth, and leverage as the control variables. The following explains the operationalization of these variables:

Table 1- Variable Operationalization

\begin{tabular}{|c|c|c|}
\hline Type of Variabl & Variable & Data description \\
\hline Dependent & Sustainable Growth (SGR) & $\begin{array}{l}\text { (net income/total equity) } \mathrm{x}(1 \text { - dividend payout } \\
\text { ratio) }\end{array}$ \\
\hline Independent & Cash Conversion Cycle (CCC) & $\begin{array}{l}\text { Cash Conversion Cycle }=\text { Account Receivable } \\
\text { Period + Inventory Holding Period }- \text { Account } \\
\text { Payable Period }\end{array}$ \\
\hline Mediating & asset utilization (TATO) & Sales/(Total Assets) \\
\hline \multirow{3}{*}{ Control } & Firm Size (FRSIZE) & Ln (Total Asset) \\
\hline & Sales Growth (SALESGR) & $\left(\right.$ Sales $_{t}-$ Sales $\left._{t-1}\right) /$ Sales $_{t-1}$ \\
\hline & Leverage (LEV) & Total liabilities/total assets \\
\hline
\end{tabular}

\section{Model Specification}

This study relies on panel data regression to test the relationship between working capital management, asset utilization, and sustainable growth in Indonesian manufacturing firms. Whereas, statistical data processing was conducted using STATA version 14. In line with the objectives of this study, we use the following two estimation models:

The first model will test the relationship between working capital management and asset utilization:

$$
T A T O_{i t}=\beta_{o}+\beta_{1} C C C_{i t}+\beta_{2} F_{R S I Z E_{i t}}+\beta_{3} S A L E S_{i t}+\beta_{4} L E V_{i t}+\varepsilon_{i t}
$$

The second model will test the relationship between asset utilization and sustainable growth, and the role of asset utilization in mediating the relationship between working capital management and sustainable growth:

$$
S G R_{i t}=\beta_{o}+\beta_{1} C C C_{i t}+\beta_{2} T A T O_{i t}+\beta_{3} F R S I Z E_{i t}+\beta_{4} S A L E S_{i t}+\beta_{5} L E V+\varepsilon_{i t}
$$

To test the mediating effect, the Sobel test was introduced by Baron and Keny (1986). If both coefficients a (the effect of the independent variable on the mediator) and $b$ (the effect of the mediator on the dependent variable) are significant, then there is a mediating effect (McKinnon, 2008). It also utilizes variations of other Sobel tests (Aroian and Goodman tests). 


\section{RESULTS AND DISCUSSION}

Table 2 demonstrates that the mean value of CCC is 138 days with a standard deviation of 68 days. The findings indicate that, on average, Indonesian manufacturing firms have quite long cash conversion cycles. Furthermore, a long cash conversion cycle indicates that firms are less efficient in managing their working capital or current assets. The inefficiency is likely due to the fact that Indonesian manufacturing firms opt for storing their inventories at a great level to ensure the continuity of their production processes. Meanwhile, the mean value of TATO is 1.08, with a low standard deviation (0.57). These results suggest that our sample firms operate with total assets that are lower than their sales. A high value of TATO implies that firms are better able to utilize their assets to generate higher sales that are eventually expected to enhance firms' sustainability growth. The mean value of SGR is 3.50 with a standard deviation of 30.12 , thus showing that manufacturing firms exhibit a positive growth.

Table 2 - Descriptive Statistics

\begin{tabular}{lcccc}
\hline \multicolumn{1}{c}{ Variables } & Mean & SD & $\mathbf{2 5}^{\text {th }}$ Percentile & $\mathbf{7 5}^{\text {th }}$ Percentile \\
\hline CCC & 138.03 & 123.92 & 67.80 & 175.43 \\
\hline TATO & 1.08 & 0.57 & 0.71 & 1.34 \\
\hline SGR & 3.50 & 30.12 & 0.88 & 10.35 \\
\hline SALESGR & 11.48 & 37.18 & -0.19 & 18.67 \\
\hline FRSIZE & 21.29 & 1.59 & 20.24 & 22.19 \\
\hline LEV & 33.68 & 45.18 & 11.98 & 42.39 \\
\hline
\end{tabular}

The correlation matrix and VIF values in Table 3 suggest that there is no serious multicollinearity problem. Specifically, the correlation between independent variables tends to be low with the VIF values approaching 1 . These results are mainly due to the advantage of using panel data that alleviates the heteroscedasticity and autocorrelation problems. Next, we run the test to determine the appropriate regression model.

Table 3- Matrix Correlation Between Variables

\begin{tabular}{|c|c|c|c|c|c|c|}
\hline & SGR & $\mathrm{CCC}$ & TATO & SALESGR & FRSIZE & VIF \\
\hline \multicolumn{7}{|l|}{ SGR } \\
\hline CCC & -0.062 & & & & & 1.21 \\
\hline TATO & 0.187 & -0.379 & & & & 1.24 \\
\hline SALESGR & 0.115 & -0.042 & 0.044 & & & 1.00 \\
\hline FRSIZE & 0.046 & -0.095 & -0.181 & 0.008 & & 1.07 \\
\hline LEV & -0.117 & 0.078 & -0.029 & -0.015 & -0.022 & 1.01 \\
\hline
\end{tabular}

Before testing our hypotheses, it is necessary to determine the appropriate panel data estimation. We then determine the Breusch-Pagan (Lagrange Multiplier) test to investigate whether the random and fixed effect models are more appropriate than common effect regression for our data panel regression. The results of this test demonstrate that random and fixed effect models are more appropriate for this study. 
Next, we run the Hausman test to select between the random and fixed-effect models. The findings indicate that the fixed effect model is more appropriate than the random effect model. Table 4 below demonstrates the results of our regression test with robust standard deviations (fixed effect robustness):

Table 4- Regression Results

\begin{tabular}{lcc}
\hline & Model I (Mediator=TATO) & Model II (Dependent Variable=SGR) \\
\hline CCC & $-0.0012^{* * *}$ & -0.0237 \\
\hline TATO & & $16.1385^{* * *}$ \\
\hline SALESGR & $0.0014^{* * *}$ & 0.1260 \\
\hline FRSIZE & $-0.3355^{* * *}$ & 3.4077 \\
\hline LEV & $-0.0002^{* * *}$ & -0.0493 \\
\hline F-test & $42.77^{* * *}$ & $5.26^{* * *}$ \\
\hline Breush-Pagan & $1904.95^{* * *}$ & $123.76^{* *}$ \\
Test/LM & $96.12^{* * *}$ & $9.72^{*}$ \\
\hline Hausman Test & & \\
\hline
\end{tabular}

The results of the Model I regression analysis above show that working capital management exhibits a direct and significant negative effect on firms' asset utilization (coef. $=-0.0012$, p-value $=0.000<0.01$ ). Firms that manage their working capital more efficiently by shortening their cash conversion cycles are better at utilizing their assets. The cash conversion cycle theory also explains that when raw materials are more quickly processed, sold, and converted back into cash, firms will arguably manage to generate higher sales growth that implies more efficient asset utilization.

Besides testing the relationship between asset utilization and sustainable growth, Model II also tests the mediating effect of asset utilization (TATO) on the relationship between working capital management (CCC) and sustainable growth (SGR). Empirically, Model II demonstrates that asset utilization exhibits a significantly positive effect on firms' sustainable growth (coef. $=16.1385$, $\mathrm{p}$-value $=0.009<0.01$ ). Our results support that asset utilization (TATO) is a factor that enables firms to achieve sustainable growth. Fonseka, Ramos \& Tian (2012) also find similar results. When firms aim to increase their sustainable growth, they have to be able to utilize their assets more efficiently or to operate more efficiently (Kester, 2002). When firms utilize their assets efficiently, they do not have to add assets to increase sales (Rahim, 2017), and firms will manage to reduce the needs of additional assets and investment costs and eventually enhance their sustainable growth (Shapiro and Balbirer, 2000).

Next, we test the mediating effect of asset utilization on the relationship between working capital management and sustainable growth. According to Wahba and Elsayed (2015), to demonstrate the mediating effect, the significant relationship between the independent variable and the dependent variable is actually unnecessary and even potentially mislead the results because this relationship represents the total effect (direct effect and indirect effect). Consequently, the mediating effect is present when the independent variable significantly affects the mediating variable, and the mediating variable significantly affects the dependent variable. In line with this argument, our empirical results show that the effect of working capital management on asset utilization and the effect of asset utilization on sustainable growth is significant, but the direct effect of working capital management on sustainable growth is insignificant (coef. $=-0.0237, \mathrm{p}$-value $=0.251>0,1$ ). Thus, our results empirically demonstrate the mediating effect of asset utilization. 


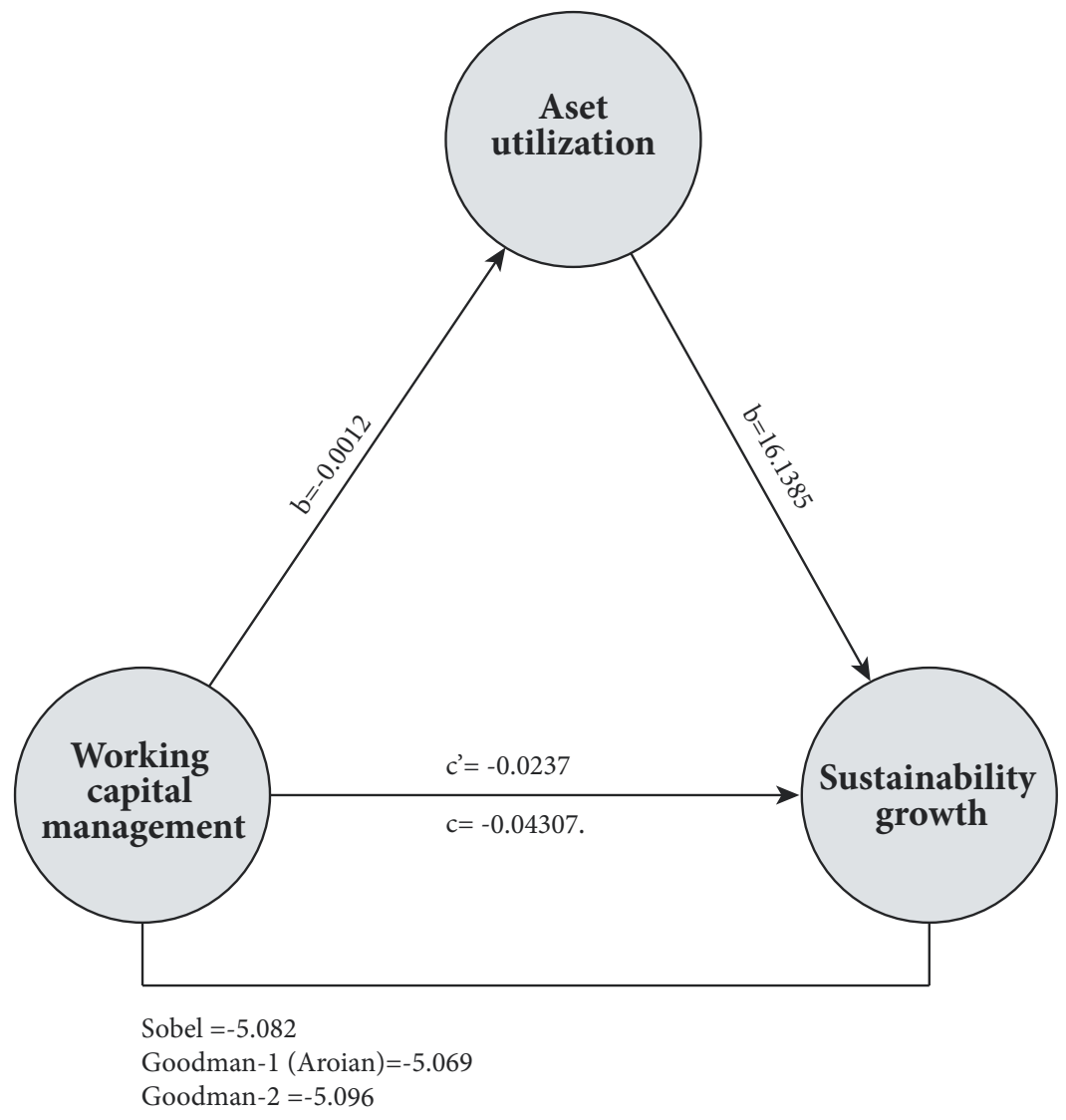

The mediating role of asset utilization is also shown in Figure 1. Sobel tests $(Z=-5,082)$, Aroian tests $(Z=-5.069)$ and Goodman-2 tests $(Z=-5.096)$ give results greater than $\pm 1.96(\alpha=5 \%)$. Thus, these results support the previous analysis which has shown that asset utilization is able to mediate the effect of working capital management on sustainable growth.

\section{CONCLUSION}

The present study investigated the ability of working capital management to increase sustainable growth through asset utilization in manufacturing firms listed in the Indonesian Stock Exchange from 2010-2017. The results demonstrate that working capital management exhibits a significantly negative influence on firms' asset utilization. Furthermore, we also find that asset utilization significantly affects sustainable growth. Moreover, asset utilization mediates the relationship between working capital management and sustainable growth. The results of this study extend the existing literature, considering that no previous studies have investigated the effect of working capital management on sustainable growth through the utilization of assets.

This research has several implications. First, that working capital management, as measured by cash cycle conversion, has a negative effect on asset utilization implies that when Indonesian manufacturing firms are able to manage their working capital more efficiently by shortening their cash cycles, they are able to utilize their assets more effectively. Shorter cash conversion cycles show shorter receivables 
and inventory cycles, so firms may invest less in receivables and inventories. In addition, shorter cash cycles also imply that firms are quicker to realize their sales that eventually increase their total asset turnover. However, this study does not test the components of working capital management (such as receivable turnover, inventory turnover, or payable turnover), which need special considerations to facilitate firms to operate efficiently. Therefore, future research can be directed to address this issue. Second, the positive effect of asset utilization on sustainable growth suggests that firms that utilize their assets better will enhance their sustainable growth. When firms utilize their assets efficiently, they do not have to add either current assets or fixed assets to increase sales. Firms might be more inclined to reduce financing costs and operate on an economical scale. Thus, firms may be able to increase their profit as a source of sustainable growth. Third, working capital management can increase sustainable growth through asset utilization. This suggests firm managers must pay great attention to working capital management because indirectly affect the company's ability to achieve sustainable growth.

Fourth, apart from this study empirically demonstrating that working capital management affects asset utilization and eventually sustainable growth, there are interesting findings to discuss regarding the extent to which the firm's sales growth must be in line with sustainable growth. In the case of manufacturing firms in Indonesia, the average sales growth was $11.48 \%$, while the average sustainable growth was only 3.50\%. When referring to the sustainable growth concept defined by Higgin (1997), sales growth in manufacturing firms in Indonesia has not been closing ideal conditions, and can even cause firms to experience financial distress. However, in practice, it does not have to be interpreted that way, considering that the SGR is built on the assumption that there is no change in financial policy. Firms rely solely on internal financing. In fact, it is possible for firms to add external financing to meet sales growth needs without causing firms to experience financial distress. Conversely, the firms also do not have to force their sales growth to be the same or close to sustainable growth due to unfavourable market conditions. For example, there is market saturation, low purchasing power, and product life cycle in the declining stage. Thus, the relationship of sustainable growth with sales growth is not something rigid. Sustainable growth should not be only viewed as a determinant of sales target policy, but also can be an input for managers to make financial policies related to sales targets.

\section{REFERENCES}

Abuzayed, B. (2012). Working Capital Management and Firms' Performance in Emerging Markets : The Case of Jordan. International Journal of Managerial Finance, 8(2), 155-179. https://doi.org/10.1108/17439131211216620

Adekola, A., Samy, M., \& Knight, D. (2017). Efficient Working Capital Management As The Tool for Driving Profitability and Liquidity : A Correlation Analysis of Nigerian Companies. International Journal Business and Globalisation, 18(2), 251-275. https://doi.org/10.1504/IJBG.2017.081957

Aregbeyen, O. (2013). The effects of working capital management on the profitability of Nigerian manufacturing firms. Journal of Business Economics and Management, 14(3), 520-534. http://doi:10.3846/16111699.2011.651626

Alarussi, A. S., \& Alhaderi, S. M. (2018). Factors affecting profitability in Malaysia. Journal of Economic Studies, 45(3), 442-458. https://doi. org/10.1108/JES-05-2017-0124

Ashta, A. (2008). Sustainable growth rates : refining a measure. Strategic Change, 17, 207-214. https://doi.org/10.1002/jsc.827

Baños-Caballero, S., García-Teruel, P. J., \& Martínez-Solano, P. (2014). Working Capital Management, Corporate Performance, and Financial Constraints. Journal of Business Research, 67(3), 332-338.

https://doi.org/10.1016/j.jbusres.2013.01.016 
Baron R.M, \& Kenny D.A.(1986). The Moderator-Mediator Variable Distinction in A Social Psychological Research: Conceptual, Strategic, and Statistical Considerations. Journal of Personality and Social Psychology, 51 (6), 1173-1182. https://doi. org/10.1037/0022-3514.51.6.1173

Botoc, C., \& Anton, S.G.(2017). Is Profitability Driven by Working Capital Management? Evidence for HighGrowth Firms From Emerging Europe. Journal of Business Economics and Management, 18(6): 1135-1155. http://doi:10.3846/16111699.2017.1402362IS

Churchil, N. C., \& Mullins, Lj. (2001). How Fast Can Your Company Afford to Grow? Harvard Business Review, 79(5), 135-143.

De Almeida, J. R., \& Eid, W. (2014). Access to Finance, Working Capital Management and Company Value: Evidences from Brazilian companies listed on BM\&FBOVESPA. Journal of Business Research, 67(5), 924-934. https://doi:10.1016/j.jbusres.2013.07.012

Deloof, M. (2003). Does Working Capital Management Affect Profitability of Belgian Firms ? Journal of Business Finance \& Accounting, 30(May), 573-588. https://doi.org/10.1111/1468-5957.00008

Fonseka, M.M., Ramos, C.G., \& Tian, G. (2012. The Most Appropriate Sustainable Growth Rate Model For Managers And Researchers. The Journal of Applied Business Research. 28, 481-500. http:// 10.19030/JABR.V28I3.6963

Ganiyu, Y.O., Adelopo, I., Rodionova, Y. \& Samuel, O.L. (2018) in Capital Structure in Emerging Markets: Evidence from Nigeria. European Journal of Applied Economics, 15(2): 74-90. https://doi.org/ 0.5937/EJAE15-17631

García-Teruel P J \& Martinez-Solano P. (2007). Effects of Working Capital Management on SME Profitability. International Journal of Managerial Finance, 3(2), 164-177.

Gorondutse, A. H., Abubakar, A., Ali, R. A., \& Naalah, M. N. I. (2017). The Effect of Working Capital Management on SMEs Profitability in Malaysia. Polish Journal of Management Studies, 16(2), 99-109. https://doi.org/10.17512/pjms.2017.16.2.09

Hien Tran, Abbott, M., \& Jin-Yap, C. (2017). How Does Working Capital Management Affect The Profitability of Vietnamese Small and Medium Sized Enterprises? Introduction. Journal of Small Business and Enterprise Development, 24, 2-11. https://doi.org/10.1108/JSBED-05-2016-007

Higgins, R. C. (1977). How Much Growth Can A Firm Afford? Financial Management, 6(Fall), 7-16.

Martínez-Sola, C., García-Teruel, P. J., \& Martínez-Solano, P. (2012). Trade credit policy and firm value. Accounting \& Finance, 53(3), 791-808. doi:10.1111/j.1467-629x.2012.00488.x

Kester, G. W. (2002). How Much Growth Can Borrowers Sustain. The RMA, (June), 49-53.

Kieschnick, R., Laplante, M., \& Moussawi, R. (2013). Working Capital Management and Shareholders' Wealth. Review of Finance, 17(5), 1827-1852. https://doi.org/10.1093/rof/rfs043

MacKinnon D.P. (2008). Introduction to Statistical Mediation Analysis. Mahwah, NJ: Mahwah, NJ: Erlbaum.

Manaf, N. B. A., Saad, N. B. M., Mohamad, N. E. A. B., Ali, I. B. M., \& Rahim, N. B. (2018). Determinants of Sustainability Growth Rate (SGR) By Using Zakon's Model To Encounter With Shariah Compliance Requirements For Shariah Securities Compliance Firms in Malaysia. International Journal of Industrial Management, 4(June), 61-69.

Laghari, F., \& Chengang, Y.(2019). Investment in Working Capital and Financial Constraints Empirical Evidence on Corporate Performance. International Journal of Managerial Finance, 15(2), 164-190. http://doi.10.1108/IJMF-10-2017-0236

Martínez-Sola, C., García-Teruel, P. J., \& Martínez-Solano, P. (2012). Trade credit policy and firm value. Accounting \& Finance, 53(3), 791-808. doi:10.1111/j.1467-629x.2012.00488.x

Marttonen, S., Monto, S., \& Kärri, T. (2013). Profitable Working Capital Management in Industrial Maintenance Companies. Journal of Quality in Maintenance Engineering, 19(4), 429-446. doi:10.1108/jqme-08-2013-0054

Molina, C.,A.,\& Preve, L.A. (2009). Trade Receivables Policy of Distressed Firms and Its Effect on The Costs of Financial Distress. Financial Management, 3(38), 663-686. 
Padachi, K., Howorth, C., \& Narasimhan, M. S. (2012). Working Capital Financing Preferences: The Case of Mauritian Manufacturing Small and and Medium-Sized. Asian Academy of Management Journal of Accounting adn Finance, 8(1), 125-157.

Palombini NNV, \& Nakamura W (2012). Key factors in working capital management in the Brazilian market. Revista de Administração de Empresas, 52 (1): 55-69. https://doi. org/10.1590/S0034-75902012000100005

Pedro Juan García-Teruel, P. M.-S. (2007). García-Teruel P J \& Martinez-Solano P. 2007. Effects of Working Capital Management on SME Profitability. International Journal of Managerial Finance, 3(2), 164-177.

Račić, Z., \& Stanišić, N. (2017). Analysis of The Determinants of Corporate Cash Holdings : Examples from Companies in Serbia. The European Journal of Applied Economics, 14(1), 13-23. https://doi.org/10.5937/ejae14-13574

Rahayu, S.M. (2019). Mediation Effects Financial Performance toward Influences of Corporate Growth and Assets Utilization. International Journal of Productivity and Performance Management, 68 (5), 981-996. https://doi.org/10.1108/IJPPM-05-2018-0199

Rahim, N. (2017). Sustainable Growth Rate and Firm Performance: A Case Study in Malaysia, 3(2), 48-60. https://doi.org/10.18510/ijmier.2017.321

Sharma, A. K., \& Kumar, S. (2010). Effect of Working Capital Management on Firm Profitability. Global Business Review, 12(1), 159-173. https://doi.org/doi:10.1177/097215091001200110

Shapiro, A. C., \& Balbirer, S. D. (2000). Modern Corporate Finance: A Multidisciplinary Approach To Value Creation. New Jersey: Prentice Hall.

Singh, H. P., Kumar, S., \& Colombage, S. (2017). Working capital management and firm profitability: a meta-analysis. Qualitative Research in Financial Markets, 9(1), 34-47. https://doi.org/10.1108/QRFM-06-2016-0018

Smith, K. V. (1973). State of the Art of Working Capital Management. Financial Management, 2(3), 50-55. https://doi.org/DOI: 10.2307/3664987

Tauringana, V., \& Adjapong Afrifa, G. (2013). The Relative Importance of Working Capital Management and Its Components to SMEs' Profitability. Journal of Small Business and Enterprise Development, 20(3), 453-469. https://doi.org/10.1108/JSBED-12-2011-0029

Wahba, H., \& Elsayed, K. (2015). The Mediating Effect of Financial Performance on the Relationship Between Social Responsibility and Ownership Structure. Future Business Journal, 1(1-2), 1-12. https://doi.org/10.1016/j.fbj.2015.02.001

Wang, Z., Akbar, M., \& Akbar, A. (2020). The Interplay between Working Capital Management and a Firm's Financial Performance across the Corporate Life Cycle. Sustainability, 12(4), 1-16. https://doi.org/10.3390/su12041661

Wasiuzzaman, S. (2015). Working Capital and Profitability in Manufacturing Firms in Malaysia: An Empirical Study. Global Business Review, 16(4), 545-556. https://doi.org/10.1177/0972150915581098

Zorn, A., Esteves, M., Baur, I, \& Lips, M.(2018). Financial Ratios as Indicators of Economic Sustainability: A Quantitative Analysis for Swiss Dairy Farms. Sustainability, 10(8), 1-20. https://doi:10.3390/su10082942 


\section{DA LI UPRAVLJANJE OBRTNIM KAPITALOM MOŽE DA POVEĆA ODRŽIVI RAST KORIŠĆENJEM IMOVINE?}

\section{Rezime:}

Upravljanje obrtnim kapitalom ima stratešku ulogu da održi ravnotežu između likvidnosti i profitabilnosti, tako da preduzeća imaju veće mogućnosti da posluju održivo. Ova studija uglavnom ima za cilj da istraži sposobnost upravljanja obrtnim kapitalom u cilju povećanja održivosti rasta korišćenjem imovine. Izvršili smo regresiju panela podataka firmi koje se bave proizvodnjom a koje se kotiraju na indonežanskoj berzi, dok nam je vremenskom period od 2010-2017 poslužio kao uzorak . Kontrolom stepena zaduženosti, rasta prodaje i veličine preduzeća, naši empirijski rezultati pokazuju da upravljanje obrtnim kapitalom negativno utiče na korišćenje imovine preduzeća. Takođe, studija otkriva da korišćenje imovine pozitivno utiče na održivi rast. $\mathrm{Na}$ kraju, empirijski pokazujemo da korišćenje imovine posreduje u odnosu između upravljanja obrtnim kapitalom i održivog rasta. Rezultati takođe impliciraju da, ukoliko indonežanske firme koje se bave proizvodnjom uspeju da efikasno upravljaju obrtnim kapitalom, postoji veća verovatnoća da će efikasno koristiti svoju imovinu, što će za uzvrat optimalno povećati njihov rast, i neće ugroziti gotov novac kojim raspolažu..

\section{Ključne reči:}

upravljanje obrtnim kapitalom, korišćenje imovine, rast održivosti, ciklus konverzije gotovine. 